Uniwersytet im. Adama Mickiewicza w Poznaniu

Wydział Neofilologii

Instytut Filologii Rosyjskiej

tel.: +48618293576

e-mail: filin@wp.pl

\title{
Концепт ад в русском интернет-анекдоте
}

Ключевые слова: интернет-анекдот, структура ада, персоносфера ада.

Одним из элементов, привнесенных христианством в культуру славян, в том числе русских, является концепт ад. По утверждению многих ученых, у язычников «понятия ада не существовало» [Лесной 1995, 242]; впрочем, как и четкого представления о месте обитания душ людей после их смерти [Gieysztor 2006, 252]. Разделение «того света» (единого мира праотцов) на рай и ад происходит именно под влиянием христианства, где понятие ада изначально толкуется как значимость духовная и материальная, ибо связывается и с состоянием, и с местом пребывания человека, отлученного от участия в жизни Божьей по его же вине [Gigilewicz 2011, 469].

Христианский ад, обволоченный мраком неизвестности, отличается высокой степенью неопределенности. В Святом Писании словом ад обозначается: гроб или могила; состояние всех без исключения усопших или «только одних нечестивых и грешников»; место, где умершие все равны, или где праведники «наслаждаются покоем», ожидая и получая избавление, а грешники «покрыты стыдом и не имеют никакой надежды на будущее»; в новозаветных книгах - вечное осуждение, погибель и мучение, «на которое осуждены грешники» [Полный православный... 1992, 65]. Ад как место изображается в виде всепоглощаю- 
щего чудовища или подземной страны, наполненной мраком и сенью смерти, или в виде подземного царства, где над умершими властвует смерть [Полныий православный... 1992, 65].

«Размыванию» понятия способствует также множество довольно расплывчатых названий ада, указанных в Святом Писании: озеро огненное и серное, геенна и печь огненная, место плача и скрежета зубов, бездна страшная, дно адово, червь неусыпающий, преисподняя и др. [«Навечно во тьме»... 2004].

Не удивительно, что ввиду отсутствия наглядного книжного представления ада обыденное человеческое сознание пытается не только адаптировать его к особенностям уже сформированной своей картины мира (в т. ч. языковой) на национальном, частном групповом и индивидуальном уровнях, но и «встроить» в свою предметную действительность. Вследствие чего у славян, во-первых, церковные «представления об аде либо смешиваются с народными, либо сосуществуют с ними, находясь нередко в противоречивом отношении и в отдельных локальных традициях, и даже в индивидуальных воззрениях» [Толстой 1995, 93]. Во-вторых, ад (кроме адского огня и мрака вечной тьмы) приобретает привычные материальные формы: котлы с кипящей смолой/водой, раскаленные сковороды, тяжелые возы, змеи, черви и пр. [Толстой 1995, 93] В страшной же караюшей силе ада, связанной с предметами обихода и терзающей плоть грешников, можно убедиться самому, напр., окунув руку в кипяток, лизнув горячую сковородку, сдвинув с места груженый водой/смолой воз и пр. Одним словом, абстрактное представление книжного ада дало человеку возможность придать наглядную форму неописанным или очерченным, но неконкретизированным образам. Как писал преподобный Симеон Новый Богослов (Гимн 8: О смирении и совершенстве): «Ибо как ад и тамошние муки всяк представляет так, как желает, но каковы оне, никто решительно не знает» [Симеон Новый Богослов преп. 2010].

Это высказывание знаменательно и по отношению к православным русским. Суть в том, что упоминания ада Святыми Отцами Церкви не носили «грубо материального» характера; в православии вообще большое внимание уделялось именно внутреннему происхождению «того состояния, что ждет человека в будущем» [Кирилл (Зинковский) иеромонах 2010]. Поэтому в узком смысле ад есть «болезнь человеческой души, особенно ясно» проявляющаяся «в ином бытии» [Кирилл (Зинковский) иеромонах 2010]; в широком «ад - это то, что наследует после Страшного суда душа, соединенная с телом, навечно» [Климов Г. протоиерей 2013]. 
Неудивительно, что такой нечеткий и неовеществленный образ ада (исключая народные представления и стереотипы) до сегодняшнего дня остается открытым для воображения и, как следствие, неоднородным. Свидетельством тому служат описания ада на тематических форумах $^{1}$. Интернетчики видят его как (в скобках - количество ответов форумчан, в кавычках - их цитаты): а) вечные душевные (8) и физические (1) муки умерших; б) место, где грешные души становятся демонами (1), место обитания грешников (7), демонов и дьяволов (5), «под землей» (1); в) вечный мрак и тьма, что связывается с холодом, изоляцией и одиночеством $(7) ;$ г) душевные муки реальных людей, т. е. их страдание, боль и страхи (3), «состояние души, когда злость, зависть, эгоизм, жадность, ревность и т. д.» (3); д) результат собственных и чужих действий (2), конкретных ситуаций (1), желаний и неисполненных мечтаний $(2)$, наслаждений $(2)$, а также того, что у человека «в голове» (7), поэтому «у каждого свой ад» (7); е) реальная жизнь «на земле» (16), в т. ч. «земное воплощение» (1), школа (1) и «наши больницы» (1); ё) «нечто непостижимое для человека» (2), бессмертие (1), фантастические картины психбольницы (1) и плачущих над разбитым лицом хоббита зеленых человечков (1), параллельный мир, который ниже реального «на уровень» (1), «понимание, что устали рождаться» (1), «состояние, когда не понимаешь, что ты умер» (1).

Итак, восприятие ада в индивидуальном преломлении больше соответствует видению его в православии, чем образу в народной традиции. Огненная, полная грешников преисподняя вытесняется «ледяным вакуумом», «холодным космосом», «поглощающей тьмой», тишиной, становясь местом «полного одиночества, где нет ни света, ни душ грешников, везде лишь мрак...»². Ад таким образом преображается в нечто нематериальное и бестелесное (неопредмеченные вечные «ду-

\footnotetext{
1 Метод сбора данных - выборка. Не учитывались ответы лиц, отрицающих идею существования ада, цитирующих высказывания других и показывающих свою непринадлежность к христианству (sdf dfs Ученик (109) в аду будут гореть те кто не принял ислам»). Материалом послужили ответы форумчан, изложивших свои представления об аде (всего 84) на форумах: Как вы представляете себе рай и ад, а также Бога и дьявола?, http://www.hristianka.ru/forum/mv/msg/1257/0/20/; Каким вь представляете себе ад и откуда ваши представления о нем?, http://otvet.mail.ru/ question/96888751; А что для вас АД?, http://otvet.mail.ru/question/21534771; Ecmь ли ад и рай по-вашему?, http://v-science.ru/view/678583/; Что для Вас aд?, http://vk. com/topic-29935768_25938551; Что по-вашему ад?, http://otvet.mail.ru/question/892 1346 [25.03.2015]. Из-за невозможности проверить принадлежность форумчан к православию, полученные данные предлагаем рассматривать как ориентировочные.

2 Форум Что для Вас ад?, http://vk.com/topic-29935768_25938551 [25.03.2015].
} 
шевные муки», беспредметное пространство). Подобное изображение созвучно одной из моделей «того света» славян-язычников, воображающих потустороний мир как что-то обособленное, застывшее и недвижимое, лишенное света, звуков, запахов, пищи и тепла [Толстой 2012, 300]. В свете сказанного интересным представляется воплощение концепта ад в русских интернет-анекдотах ${ }^{3}$.

Они не являются единым речежанровым целым, т. к. к ним относятся анекдоты:

- аудиовизуальные, т. е.: игровые экранизации анекдотов (1); выпуски передач, посвященных анекдотам (Луишие анекдоты из России), фрагменты юмористических передач, концертных выступлений и под. (2); видеоверсии анекдотов, рассказанных и размещенных частными лицами в Сети (3); фрагменты новостных, публицистических и других передач, участники которых рассказывают анекдоты к слову или по просьбе ведущего (4); анимационные экранизации $(5)^{4}$;

- аудиоанекдотьи (http://anek-dot.ucoz.ru/stuff/);

- визуальные в виде комикса, картинки плюс анекдоты, проиллюстрированные стоп-кадрами из кинофильмов или одной фотографией/картинкой, которая изображает главную анекдотную ситуацию или раскрывает тему анекдота ${ }^{5}$.

Сосредоточимся, однако, на четвертой группе анекдотов, размещенных в текстовой форме на юмористических порталах, форумах, персональных сайтах и т. д.

Выборка насчитывает 160 анекдотов, поставленных на сайтах с заглавием типа «Анекдоты про ад (пекло, преисподнюю)» ${ }^{6}$; разные варианты анекдота расцениваются как одно целое. Тексты, которые не

3 Интернет-анекдоты - условное название анекдотов, размещенных в Сети.

4 Примеры указанных разновидностей интернет-анекдота: (1) http://www.anekdot. ru/an/top/M0703-0704,30.html; (2) https://www.youtube.com/watch?v=g_1lJr4xZIY; http://rutube.ru/video/af15426d09b48d7b62f5e78422710872/?ref=search; https://www. youtube.com/watch?v=J-a0Rya2OLs; (3) https:/www. youtube.com/watch?v=rHvny3 Ceaak\&feature=youtu.be\&a; (4) http://rutube.ru/video/955fad679436568f19c4ba87882 ed3d3/?ref=search; http://rutube.ru/video/8c63c565570f681380adfa05d0d7c7e6/; https: //www.youtube.com/watch?v=95-_s14v-dE; (5) http://rutube.ru/video/a882c83b7f5a71e b71108c3cb9f80254/?ref=search; http://rutube.ru/video/3a9de399b5ab1c 84e32675b92ce ea1b7/?ref=search [22.03.2015].

5 Соответственно: http://happylol.ru/anekdoty/750-illyustrirovannyy-anekdot.html, http://www.ejin.ru/prikoly/pro-ad-i-ray.html; http://smeshnye.pro/smeshnye-kartinki/27 2-ugarnye-anekdoty-v-kartinkah.html; http://prikolnye-smeshnye.ru/anekdoty/6-anekdot y-v-kartinkah.php; http://spirit-ninja.ru/?p=592; [22.03.2015].

6 Cм.: http://000a.ru/a/tag/2105/10; http://anekdoty.ru/pro-ad/; http://anekdoty.ru/ 
могут быть предварены «"метатекстовым" вводом» [Шмелева, Шмелев 2002, 30], в выборку не входят. Это истории (Брусничка, http:// www.vysokovskiy.ru/anekdot/ada/1/), прибаутки (Меня в ад??? А черти-то беднье в чем виновать???), шутки (Билл Гейтс после смерти попадёт не в рай и не в ад, а в Корзину), приговорки (Вот раньше жизнь была: РАЙком, РАЙисполком, а теперь сплошная АДминистрачия!), пародии (Компания «Тефаль» заключила контракт с Адом на поставку антипригарных сковородок. «Тефаль» - тьи всегда думаешь о нас!), анекдоты в стихах (Есть на свете в мире ад, // Это пробка утром МКАД!), анекдоты-притчи (http://anek-dot.ucoz.ru/news /raj_i_ad_sereznoe/2011-11-16-2530), статусы или анекдоты-афоризмы (Труднее всего поджечь ад; Вечнье каникуль - хорошее определение ада; А что, если наша Земля - ад какой-то другой планетье?).

Собственно метатекстовый ввод анекдотов типа «А давайте анекдот расскажу», «Слышала новый анекдот?» и «Хочешь, анекдот прочитаю?» заменяется темой сайтов/веб-страниц [Ерофеев 2010, 164], напр., Пекло, Анекдоть про ад, или темой самого анекдота Развалили ад, Праздник в аду (http://000a.ru/a/tag/2105/10). «Адская» тема задается также зачином типа «Идет экскурсия по аду», «Умер студент. Попал в ад», но не всегда, т. к. в зачине многих анекдотов «про ад» говорится о рае, небе, райских вратах, о «том свете», напр., «Умер мужик - попал в рай». Иногда загробный мир в зачине вообще не упоминается («Армянское радио спрашивают»).

Вовлеченность «адских» анекдотов в интернет-коммуникацию ограничивается их напоминанием и цитированием, оценка - проставлением лайков, голосованием $(+/-)$, оцениванием по пятибалльной или другой системе $(-2,-1,0,+1,+2)$ или комментариями, обычно сводимыми к благодарности («спасибо - смешно!!!»), описанию своих реакций («Посмеялась))»), к краткой оценке («зачОт»), к околоанекдотическим замечаниям («многие преподы юмор не понимают...»)7. Широкие обсуждения анекдотов «про ад», как в случае других тематических групп анекдотов (http://www.anekdot.ru/an/an0109/g010919.html),

pro_ad/; http://ucrazy.ru/anekdot/1284868508-anekdotyproadrajdemonovangelovsmert.h tml; http://www.vysokovskiy.ru/story/adom/ [22.03.2015]. В выборку включены также отдельные анекдоты, выложенные в социальных сетях (напр., Вконтакте), на форумах и персональных страницах, озаглавленных Анекдот про ад/пекло, O пекле и пр.

7 См., соответственно: http://otvet.mail.ru/question/43806941; http://www.vysokovs kiy.ru/anekdot/ada/1/; http://esoterick.ru/post294020999/; http://ptz.karelia.pro/view topic.php? $\mathrm{p}=330790$ [28.03.2015]. 
не встречаются. Отсюда, налицо усиление их развлекательной функции и ослабление, если не нивелирование, фатической.

Среди анекдотов «про ад» находятся тексты довольно короткие 8 и длинные, предназначенные, скорее, для чтения (http://ptz.karelia.pro/ viewtopic.php?p=330790).

Анекдотный ад, будучи частью загробного мира, предстает как: 1) плод фантазии верующих, иногда опредмеченный: 2) нечто весьма комфортное и приятное, что не всегда осознается грешниками: 3) действительно что-то страшное ${ }^{9}$.

В пекло можно попасть пешком через врата, которые могут находиться рядом с райскими (см. сноску 28), на лифте и на поезде ${ }^{10}$. Вход охраняет «привратник в черном одеянии», черт или дьявол.

Место расположения ада на «том свете» или не определено, или рядом с раем (через стену), или ниже рая ${ }^{11}$, или в том же самом месте, что

8 - Дети, кто будет учится на 4 и 5, mот попадет в рай. A кто будет учиться на 2 и 3 - в ад! Вовочка: - Мариванна, а что живым закончить школу нельзя?! Анекдоты приводятся без изменений, т. е. с оригинальной записью слов и пунктуацией.

9 А) В ряде анекдотов разделение «того света» на ад и рай отсутствует: Bcmpeчаются двое на том свете. - Kак тьл сюда попал? - Упал с 16-этажного дома. A тыз? - Смотреть надо куда падаешь! Б) Соответственно: 1) Попал мужик в ад. Встречает его черт, приглашает прогуляться по аду: - Вот здесь у нас казино, там ресторан, напротив бордель, стриптиз, для желающих-музей, кино, библиотека. Все работает круглосуточно, услуги бесплатные. Проходят мимо какой-то двери. А там крики, стонь, запах серьл. Мужик спрашивает: - A здесь ито? A это ад для верующих. - Как это? - A так. Что себе понапридумали, то и получили. 2) Попадает мужик в рай. Кайфует там. Все хорошо: люди, еда, даже бабы. И спрашивает архангела: - А можно одним глазком на ад взглянуть? Дают ему посмотреть, а там ровно все то же самое, включая ландшафт, но люди почем-то плачут и страдают. - Почему все они такие несчастные? - спрашивает удивленныи мужик. - Да просто они думают, ито в раю лучше... 3) Американеи, немеи и русский попадают в ад. Американец: - Какой здесь ужас! Немец: - Какой здесь кошмар! Русский: - Да, действительно хреново, но не хуже, чем в нашем санатории....

10 Умер мужик. Сидит на небесной сортировочной станции, ждет своей участи. Мимо проходит поезд с табличкой «B Ад». Делает короткую остановку, и тут в окне напротив мужик видит свою тещу. Мужик ненадолго опешил, потом совладал с собой и говорит: - Мама! Рад вас видеть! Вы куда, на прочедурь или на работу?

11 Мужик помер, попал на тот свет. Архангел ему и говорит: - Ть и не грешник и не праведник, выбирай, куда хочешь попасть - в рай или ад. - А можно на них посмотреть? - Можно. - Тогда давай сначала в рай. Сели в лифт, поехали. Лифт останавливается, двери открываются. Перед ними комната, в комнате огромная кровать, везде подушки, на потолке зеркало. На кровати между двух шикарных блондинок лежит дедок. Мужик: - Ух ть! Давай в ад. Поехали вниз. Двери лифта открываются, перед ними та же картина. Мужик: - Это ад? - Да. - А в чем разница? - Видишь ли, все относительно - что для одного рай, то для другого сущий ад. 
и рай: Умер программист. Попал на Страшный Суд. Судили-рядили ни то, ни се. - Куда сам-то хочешь, в ад или в рай? - A посмотреть можно? Привели его в громаднейший вычислительный чентр. Кругом машин всевозможньи, сеток видимо-невидимо. Вот это - рай, будешь здесь юзером. - $А$ ад? - $А$ ад здесь же - только системщиком.

Многоуровневой структура ${ }^{12}$ ада обычно представляется в анекдотах про геймеров, квакеров и думеров, причем пекло не является самым нижним уровнем «того света», т. к. ниже располагается бар ${ }^{13}$. Ад часто изображается в виде коридора со множеством дверей; за каждой из них грешники подвергаются конкретным наказаниям ${ }^{14}$ или мучаются конкретные индивиды (http://anekbook.ru/10381).

Иногда пекло разделяется на два ада по национальному признаку (русский - американский/немецкий), принадлежности к определенному строю (социалистический - капиталистический) или на школьный/обычный и студенческий.

Описания организации труда чертей в русском/социалистическом аду содержат автостереотипы русских относительно своей действительности: «В русском аду то дров нет, то котлы испорчены, то черти пьяные»; «В социалистическом аду то спичек нет, то с топливом перебои, то котел на ремонт поставят, то у чертей партсобрание». На радость грешникам длительные и частые сбои, некачественный труд и халатное отношение чертей к работе оборачиваются для них плюсом. Хотя в социалистическом аду в конце месяца иногда объявляется

12 Попал как-то думер в ад. Ну, натурально, не подкачал - пилит всех чертей налево и направо. Из рая за ним наблюдают, есессна, с интересом. Прошел он все 7 кругов, и выщел на тропинку, ведущую в рай. Ангель победителя приветствуют как положено: с трубами, с хлебом-солью ... Думер, причеливаясь: - Рулез! 8-й уровень!!!

13 Умирает Путин, попадает в рай, и там захотелось ему увидеть Ельиина. Он подходит $\kappa$ апостолу Петру и спрашивает, где может увидеть своего предшественника. Тот отвечает, что Ельцина в раю никто не видел и советует поискать его в чистилище, но и там Путин его не находит. Тогда, решив, что Ельиин в аду, Путин спускается туда, находит там Сатану и спрашивает у него: - Простите, Ельиин, случайно, не у вас? - Нет, здесь его никогда не было. А ты не искал еще ниже? - Еще ниже?! Простите, но после рая, чистилища и ада что может бьть еще ниже? - Как ито? Бар!

14 Попадает мужик в ад, идет по коридору. Открьввает первую дверь - там кого-то в котле варят. - Отбегает в ужасе, открывает следуюшую дверь - там кого-то на дыбу вешают. Открьвает следуюшую дверь - там мужики стоят по пояс в дерьме и курят. Ну, думает, лучше в дерьме постоять, чем в котле свариться, прыгает в дерьмо, тоже стоит и курит. Тут открывается дверь, заходит черт: - Ну что, покурили? A теперь доедайте. 
аврал: «то молоток сломан, то гвозди не завезли, то чёрт на работу не вышел... но в последний день месяца все тридцать гвоздей в ж... получишь!» Четко налаженная работа чертей в американском/немецком и капиталистическом аду - не что иное, как позитивный гетеростереотип русских о заграничной реальности.

В школьном и студенческом аду «производственный» процесс протекает с учетом выполнения учебных обязанностей учащимися в школах и вузах. Поэтому, исходя из того, что студенты должны успешно сдать сессию, а школьники - каждый день учить уроки, в студенческом аду черт вбивает ведро гвоздей в задницу грешникам раз в четыре месяца («Сессия, чуваки!»), а в школьном - по одному гвоздю ежедневно (анекдот №3: http://www.anepedia.org/Анекдоты_про_ад).

В трех анекдотах пекло разделяется на две части: в одной развлекаются безбожники, в другой караются верующие греховодники (http:// www.ateism.ru/laugh\&sin/index.html?perpage=20\&start=500). В других анекдотах ад являет собой безграничное пространство, являющееся местом или мучения грешников или порочных утех ${ }^{15}$. В каждом из этих видов ада обязывает соответствующий дресс-код: в двух анекдотах развлекающихся грешников облачают в красный костюм, а «новых русских» в красный пиджак и золотые цепи; в одном анекдоте мученики получают рабочие комбинезоны.

Если говорить о сходстве и различиях пекла и рая в анекдотах «про ад», то полное их подобие встречается редко. Только в двух анекдота ад - точная копия рая (см. сноску 11), и лишь в одном рай - полная копия ада ${ }^{16}$.

Обычно эти миры разнятся одним элементом ${ }^{17}$. или диаметрально. В последнем случае ад рисуется как место вечных телесных мук,

15 Умирает мужик, попадает в ад. Ходит везде, осваивается. А в аду на каждом углу бары, рестораны, казино, шикарные девицы на любой вкус - словом, сплоиньее удовольствия и вечная теплая ночь. Мужик задумался: почему так? Подходит $\kappa$ служителю Сатань - крупье и спрашивает: - Почему же нас уверяли, что ад - это вечныи костер для грешников и вечные муки? - Да просто нашу неоновую рекламу сверху за огонь принимают!

16 Попал мужик на тот свет. Ангель сказали - в рай. Он заходит в ворота а там котльи, сковородьл... - Ааа!!! Это ж ад! - Не, мужик, ты посмотри кто в котлах! А там начальник, теща, гаишник и сосед... - Ффууууу!!! Рай!!!

17 Попал мужик в ад. Видит сидит черт на горе анаши. Мужик попросил у него жменю анаши, черт отвечает: «Бери сколько хочешь». Мужик взял. Потом мужик подходит и просит ведро анаши, черт ему: «Бери сколько хочешь». Мужик подходит и просит огонька, а черт ему: «Мужик, если б тут был огонек, это был бьл не ад, а рай». 
для чего используются котлы с кипящей водой/смолой/маслом, сковороды, дыба, бассейны с фекалиями, пылающий огонь; греховодников, чтобы не дергались, приковывают к стене или привязывают к столбу/стульям. Кары соответствуют народным представлениям, т. е. грешников варят, жарят, сажают на кол, заставляют лизать раскаленные сковороды и ворочать тяжелые камни, подвешивают на дыбе, рвут куски мяса из тела. Кроме традиционных наказаний используются вбивание гвоздей в зад и иголок под ногти, приседания в бассейне с фекалиями, поедание фекалий, изнасилование, принуждение к оральному/анальному сексу, содомизирование, обязательное участие в диких оргиях, а также «экологически чистые методы», т. е. битье палками и сортировка-расфасовка гадкого мусора по пластиковым пакетам голыми руками.

В одном анекдоте говорится, что кара меняется каждую тысячу лет, еще в одном представлен график развратных утех: по понедельникам все курят «от трубки и махорки до дорогих сигар и кальяна»; по вторникам все пьют алкоголь; среда - день принятия наркотиков; четверг - «день повального секса»; пятница - праздник для гомосексуалов (www.todayanekdot.ru/anekdot/wednesday).

Некоторые греховодники подвергаются душевным терзаниям, напр., испытывая стрессовую ситуацию на работе («через час дедлайн, а еще ничего не готово»), или выполняя что-то по принуждению (Б. Гребенщиков обязан жениться на «жуткой старой бл*ди», Патрисия Каас - выйти замуж за Е. Летова, грешный муж - «наслаждаться» ландшафтом из пластика и музыкой Шостаковича в обществе надувной девицы). Для избранных групп грешников придумываются специальные муки: инспекторы ГИБДД, оставаясь на своих постах, «не могут никого ни тормознуть, ни оштрафовать, ни взять взятку»; работники ЖKXX, «отключавшие летом горячую воду», замерзают в ледяном озере; сладострастные мужики, окруженные сексуальными блондинками, лишаются возможности заниматься с ними любовью, «новые русские» - развлекаться в злачных местах, пивоманы - баловаться холодным пивком в жару, а наркоманы - курить косячки, хотя все доступно в изобилии.

Для самых злостных грешников отводятся «большие комфортабельные viр-котлы» и целые VIP-залы. Если же простые места и VIPкомнаты в аду комфортные или аналогичны неудобным райским («тесная, прокуренная комнатенка, набитая работниками творческого труда»), то наказанием служит: а) род занятий (см. выше анекдот про программиста); б) выполняемое задание, напр., Билл Гейтс «без оши- 
бок пишет программу Windows», Гитлер «Карла Маркса на иврит переводит»; в) завершение работы, напр., в раю бухгалтеры успевают сдать отчет, а в аду - нет.

Парадоксально, но в пекле существуют не только «отдельные номера со всеми удобствами» для «заслуженных» грешников типа Фидель Кастро/Порошенко (http://anekdoty.ru/pro-ad/), но и райские уголки для праведников, напр., для химика-фармацевта, которого черти, перехватив у «райской конкуренции», наградили за изобретение «Виагры» вечным наслаждением (http://anekbook.ru/10381/). Более того, в ряде анекдотов говорится, что лучше живется людям в аду, т. к. там «развлечение за развлечением», «движуха - бухняки, телки, наркота», танцы (http://anekdoty.ru/pro-ad/). В раю же скукота, т. к. «все на качелях качаются», «кругом ангелочки голозадые порхают», в облаках ангелы играют «на золотых арфах», обсыпают праведников лепестками роз, а те молятся или «за партами сидят и передовицы из газет читают», или тяжело работают, ибо «каждый день нужно возить молоко на Млечный Путь, начищать звезды, подталкивать облака». Мало этого, в раю кормят одной тушенкой и килькой в томате, а в аду «народ жрет балыки, икру и ананасы», «жареных рябчиков и марципаны», омаров, попивает вина, водку, пиво с рыбкой.

В ад грешники направляются согласно заранее составленным спискам или по решению Страшного Суда, Святого Петра, Архангелов, ангелов, Архангела Гавриила, Господа, а также в результате дискуссии Бога/ангела с Сатаной/чертом, по ошибке или по собственному желанию. В трех анекдотах грешники поддаются испытанию: Святой Петр задает брюнетке, блондинке и шатенке вопрос «Что такое Пасха?» или бьет книгой их же грехов по голове; черт бьет русского, американца и индуса три раза кнутом. Кто ответит неправильно или не выдержит удара, тот идет в ад. В случае сомнений, куда направить преставившегося, человек получает право самостоятельно выбрать место вечного пребывания, или его отправляют обратно на землю «совершить какой-нибудь поступок», или перед отправкой в ад Бог/черт исполняет три желания. В двух анекдотах праведницы сами просятся в ад, испугавшись физических мучений, через которые надо пройти, чтобы очутиться в раю, т. к. прибывшим сверлят дырки в спине и черепе под крылья и нимб, а с ног сдирают кожу, «дабы не пускать в рай всю грязь земную, приставшую к ногам».

В аду грешникам тоже иногда предлагается самим избрать место нахождения или вид наказания. Мучений избегают лишь фидошник, рассказывающий анекдоты с разрешения черта, поп и раввин, отку- 
пившиеся баксами по предложению Лукавого, а также Березовский, приучающий чертей к коммерции по собственной инициативе.

Не страшен ад учителям, москвичам, пережившим страшную жару в 2010 году, и русским, привыкшим к экстремальным условиям ${ }^{18}$.

В аду устраиваются не только праздники, когда отключают горячую воду, но и экскурсии для: а) простых туристов, которым «в назидание демонстрируют грешников, насильников и убийц, подвергающихся разным суровым наказаниям»; б) отдельных лиц по их просьбе или в качестве бонуса, чтобы они выбрали себе кару или место на «том свете» (напр., в аду/раю, в аду немецком/русском); в) праведников и грешников с целью разрекламировать преисподнюю, представив ее в выгодном свете, и завлечь в нее как можно больше людей ${ }^{19}$, хотя в аду мест на всех иногда не хватает.

Из рая праведники могут перебраться в ад по личной просьбе и с разрешения Господа; из пекла в рай можно убежать или перейти на законных основаниях «отмотав свой срок в аду». Перемещаться из рая в ад и наоборот можно в лифте, по тропинке или по дороге. Связь между двумя мирами осуществляется через адово посольство в раю, по телефону, с помощью телевизора, личного общения и писем ${ }^{20}$. В четырех анекдотах упоминается суд, через который Господь пытается призвать черта к порядку. Однако каждый раз оказывается, что все адвокаты/судьи сидят в аду, о чем черт, чувствуя свою безнаказанность, радостно Ему сообщает.

За помощью черти/Сатана обращаются к Богу в случае разрушительных действий грешников и их пагубного влияния на чертей. На-

18 Мужик попал в ад. Его отправляют рубить лес при жаре 70 градусов. Приходят проверять, мужик довольньий, рубит лес, песни поет. И объясняет, что, мол, у него дома (на Земле) 70 градусов это фигня, легкая прохлада, можно сказать. На следуюший день его отправляют рубить лес при жаре 130 градусов. Но картина повторяется. Тогда его отправляют валить лес при морозе в 40 градусов. Приходят проверять, он счастливый, аж танчует на радостях. Его спрашивают, что за причина для счастья. - Ну как же! Ведь в аду идет снег! Значит наши выиграли чемпионат мира по футболу!

19 Мужик в раю получил путевку в ад. Поехал. Сплошные пьянки, женщины, наркотики. В общем, кайф сплошной. Понравилось. И как только вернулся в рай, сразу в адово посольство, попросил политического убежища. А в аду его сразу в котел с кипящим маслом кинули. Он: Мол, как же так, у вас тут так хорошо было, а как приехал, сразу в кипяток бросаете! А ему говорят: Ты, батенька, туризм с эмиграцией не путай.

20 Сидит Сатана и пишет письмо ко Всевышнему: - Господи, забери себе этого хакера, попав ко мне, он решил что это очередная версия DООМа и гольми руками передавил половину моих чертей. 
пример, любители компьютерных игр способны перерезать бензопилой всех чертей и даже отпустить грешников на землю; «новый русский» - завести в аду свои порядки («часть чертей у него в братве, остальная - в ментах или в барах, ресторанах работают», «везде перестрелки, разборки за сферы влияния»); старый коммунист - навязать свою идеологию («пропагандой своей совсем достал, чертенят в пионеры принимает»), а Ленин - устроить бунт («черти восстание подняли, за адский труд требуют райских условий жизни»); «голубой»- замучить чертей своей похотью ${ }^{21}$; Яценюк с Порошенко - заморозить весь ад, а Ельцин с Гайдаром - его развалить. Только в одном анекдоте черти предлагают небожителям устроить товарищеский матч по футболу.

Персоносфера ада четко разделена на работников «адского труда» и грешников. У первых наблюдается строгая иерархия: Главный, черти и чертенята. Ни в одном анекдоте «про ад», в противовес другим ${ }^{22}$, чертихи не встречаются. Люцифер, Вельзевул, бес, демон, Лукавый, Главный смотритель и некто «похожий на человека, но светящийся изнутри инфракрасным светом» реже выступают в анекдотах (в 1-2, не считая вариантов), чем Сатана, черт и дьявол. Некоторые черти работают в качестве стражника, привратника, бармена, крупье, кочегара, охранника, ревизора. Черти и дьяволы изображаются традиционно, т. е. с рогами и хвостами, с кошмарными злыми рожами, «со свиными рылами» и зловещей ухмылкой, а также с кнутом, дубиной, пикой или вилами в руках. Один раз черт облачается в красный костюм и раз в «черное одеяние». Из обуви только у дьявола имеются тапки.

Характер рядовых чертей угадывается по их поведению. Они предприимчивые и хитрые, поскольку успешно рекламируют пекло, предлагая грешникам самим избрать кару и при этом искусно скрывая от них всю «адскую подноготную»; падкие на деньги; исполнительные; податливые на пропаганду (восстают против Сатаны) и переимчивые, т. к. легко адаптируются к навязанным им грешниками условиям и образцам поведения (напр., халатно относятся к труду в соцпекле); слабо-

21 Умер «голубой». Ангел, не зная куда его отправит, стал монетку кидать. Пока он наклонялся, чтобь ее с пола поднять, «голубой» все сзади ангела пристраивался. За это ангел отправил его в ад. Спустя пару недель проходит ангел мимо ада, а там холод, тишина, печи не горят, сковородьи все остьли. Ангел чертей спрашивает: - Что это у вас случилось?! - Неужели непонятно, ты же сам $к$ нам «голубого» прислал! - Ну и что?! - A ты попробуй $к$ печке наклониться дрова подкинуть...

22 Папа-черт пришел домой после работь, а жена-чертиха подводит $к$ нему сына-чертенка и говорит: «Сегодня можешь его отшлепать - весь день вел себя как ангел». 
характерные, ибо не способны удержаться от выпивки/гулянки (http:// pikabu.ru/story/prosto_evreyskiy_anekdot_2545615), а также дать отпор русским $^{23}$, геймерам/хакерам и гомосексуалу (см. сноски 20, 21).

Несмотря на то, что дьявол и черт открыто предлагают адвокату и «новому русскому» заключить сделку (богатство плюс выигрывание всех процессов за души умерших родственников или три желания за душу самого грешника), искушаемые подозревают их в коварности, не понимая, в чем подвох.

В анекдотах главный черт/Сатана по характеру стойкий, неуступчивый и глупый, т. к. исполняет желания геймера, давая ему оружие, боеприпасы и бесконечные хелсы (в компьютерных играх - жизни). Сатана описывается еще как «человек любезный, веселый и симпатичный», хотя слабонервный (разрыдался, жалуясь Богу на геймеров, убивших всех чертей), а Люцифер - как гостеприимный.

В обращении Сатана/черт ласков со студентами и довольно вежлив с Господом и высокопоставленными грешниками; отвечает на все вопросы и успокаивает студента: «Не бойся заранее, здесь на самом деле намного лучше, чем описывают там, на земле». Он использует обращения мужик и батенька к мужику, батюшка к Гундяеву, сынок к студенту, друг мой к Путину, Господи, Боже, Бог к Всевышнему, ребята к чертям, а также уменьшительные формы имен, напр., Колюня Щелоков, Вова, Боря Пуго. С Кастро, Порошенко, Ельциным и Гундяевым разговаривает на «вы», с остальными на «ты». Стиль речи Сатаны - разговорно-бытовой; в одном анекдоте он употребляет бранные слова сволочь, гад, бл@ и заимствованное $O K$, а черт - просторечные дык, ента, ентот и разговорно-сниженные чудило, порешить и перемолоть в значении убить». Несмотря на эти особенности, в анекдотах отсутствуют языковые маски чертей и других обитателей ада ${ }^{24}$, хотя персоносфера грешников весьма разнообразна. В нее

23 Приезжает комиссия в АД с проверкой. Водит ее (комиссию) главный черт, показьвает как грешники варятся. Подошел председатель комиссии к котлу с русскими, смотрит - а там вода не кипит, сунул руку, а она просто теплая! Подходит к другим котлам - там все как полагается, вода - крутой кипяток! Он и спрашивает у главного черта: почему так? А тот отвечает: «Понимаете, русских лучше из себя не вььодить. Если их разозлить, они не только сами вылезут и всех остальньх освободят, да еще нам, чертям, рога поотиибают и самих в котел вариться посадят!»

24 А) Сказанное касается и небесных обитателей. Их речь ничем не отличается от речи чертей и грешников. Б) В одном анекдоте говорится, что в раю общаются на латыни, а в аду - по-немецки (как вариант - в раю на иврите, а в пекле - по-русски). 
входят представители разных национальностей, конфессий, исторические лица, атеисты, политики, богачи, специалисты, компьютерщики, женщины, мужчины, герои художественных произведений и преступники (подробнее см. Таблииу 3).

Среди обитателей ада встречаются реальные лица, собирательные образы, художественные и вымышленные персонажи, скажем, Патрисия Каас - блондинка - Гермиона - «прожженная проститутка $K э m \gg$. Меньшинство составляют женщины, герои книг/кино и кот ${ }^{25}$; подавляющее большинство - мужчины. Наиболее почитаемые из них: Фидель Кастро, Порошенко и изобретатель «Виагры», проживающие в комфортабельных комнатах, а также Данте, работающий в аду экскурсоводом, и сантехник, которого черт выпросил у Господа «на недельку» починить оборудование, но не пожелал отдавать обратно столь ценного специалиста. Одна часть анекдотных грешников - типажи («старый член КПСС»), персонажи (Терминатор) и лица советских времен, 90-х годов XX в. и «нулевых» XXI в. (не)российской действительности или (не)русской культуры; вторая - вневременные типажи, напр., неверные мужья, теща. Среди обитателей ада нет детей, бабушек и бедных.

Многие перечисленные грешники выступают в роли пассивного персонажа, что больше характерно для анекдотов с вопросно-ответной структурой ${ }^{26}$, или фонового персонажа, который обычно упоминается в тексте «от автора» ${ }^{27}$ или в разговоре главных героев («А вот здесь варятся немцы»). Количество активных персонажей обычно не более четырех. Общение между ними происходит в диаде преставившийся - репрезентант рая/ада, репрезентант ада - репрезентант рая/ада, преставившийся грешник - преставившийся праведник/грешник, живой - репрезентант ада/рая, живой - живой, а также (в одном анекдоте) живой - воскресший, преставившаяся праведница - репрезен-

25 Вовочка: - Мам, а где наш котик? - В аду, сынок, в аду. Ссыт, сука, в тапки дьяволу.

26 - Что такое Рай? - Это такое место, где все повара - Франиузы; все гувернерь - англичане; все кинорежиссерь - американиь; все домохозяйки - русские, а вся администрация состоит из немиев. - А ито такое Ад? - Это такое место, где все повара - англичане; все гувернерь - франиузы; все кинорежиссеры - немиь; все домохозяйки - американки, а вся администрачия состоит из русских.

27 Фоновый персонаж - Гитлер: Попал Брежнев в ад. Его черти в котел засунули и давай варить. Вдруг Брежнев замечает, что рядом с ним сидит Гитлер. Закинул ногу на ногу и читает книжку. Возмущенный Брежнев кричит: - Я что, больше него нагрешил?! Что это, я тут мучаюсь, а он там книжку читает?!?!?! - Это он не книжку читает. Это он Карла Маркса на иврит переводит. 
тант рая. Монологическая речь, точнее, обращение репрезентанта рая к преставившимся ${ }^{28}$, и отсутствие монолога/диалога встречается лишь в одном анекдоте (http://humor.rin.ru/cgi-bin/show.pl?anekdot= 28966\&razdel=0).

В референциальных (ситуативных) анекдотах описанные ситуации отличаются как прикрепленностью к конкретному периоду, напр., к советским временам (см.: http://ru.loolz.org/index.php?title=Анекдоты_ про_Ад_и_Рай), так и вневременностью. Последнее способствует обновлению содержания путем замены одних персонажей другими ${ }^{29}$. Типичность же некоторых ситуаций в анекдотах «про ад на земле» содействует перенесению места действия из одной национальной культуры в другую с помощью смены имен персонажей ${ }^{30}$.

Несмотря на то, что в референциальных анекдотах действие часто происходит в ирреальном пространстве загробного мира и с участием вымышленных персонажей, основной чертой анекдотного ада является его узнаваемость. Иначе говоря, пекло есть модифицированная версия мира реального, поэтому для каждого элемента анекдотного ада найдется соответствующий ему элемент земного мира. Например, многоуровневая структура ада напоминает многоэтажное тюремное здание; адские врата - вход в концлагерь/колонию; подход чертей к грешникам (не говоря уже о человеческих чертах характера чертей и их поведении), в т. ч. с учетом национальной принадлежности ${ }^{31}$, - отношение тюремщиков к заключенным, в жизни негласно делимых на равных и более равных со всеми вытекающими последствиями; адские кары

28 У ворот Ада и Рая апостол Петр собрал женщин: - Все в ряд. Кто хоть раз изменял мужу - шаг вперед. Все шагнули вперед, кроме одной - честной женщины. Апостол Петр: - Ну что ж. Все в Ад и глухая тоже.

29 Например, Фиделя Кастро заменили Порошенко, сp.: http://humor.rin.ru/cgi-bin /show.pl?razdel=0\&anekdot=39394 и http://anekdoty.ru/pro-raj/page/2/ [01.05.2015].

30 Например, смена имени фонового персонажа переносит действие из русской семьи в немецкую или еврейскую: - Папа, я не могу выйти замуж за Константина/Людвига/Изю! Он - атеист и не верит, что существует ад. - Ничего, дочка. Смело выходи за него. Тьи и твоя мамочка очень скоро сумеете убедить его, что он глубоко заблуждается!

31 Идет экскурсия по аду. На одном котле очень много крышек и он завален камнями. Экскурсанты спрашивают экскурсовода, почему. - Здесь варятся евреи. Если хотя бы один сумеет выбраться, обязательно перетащит всех остальных. Дальше экскурсанты видят котел, который не прикрыт ничем. Экскурсовод: - Здесь русские. Мы за них не боимся. Даже если один сумеет выбраться, другие все равно затащат обратно. Дальше наблюдается третий котел, на котором тоже ничего нет. - Здесь немцы. С ними вообще просто. Мы начертили линию и написали «не перелезать». 
- пытки, придуманные самим людьми (напр., опричники разрубали осужденных на части живыми, жгли на сковородах, перепиливали веревкой, вгоняли иглы под ногти, сажали на кол и пр.). Контакты представителей темных и светлых сил отображают реальные интеракции и взаимоотношения между прокурором и судьей/адвокатом, братвой и ментами, где первые - адского, вторые - райского роду племени. Узнаваемы и ситуации типа инвентаризация котлов, аудит, комиссии, реклама ада, экскурсии, а также предметы (печка, дрова, сигары, «компы навороченные»), природное и животное окружение (зеленая травка, поле конопли, мухи, вороны, щуки), формы отдыха (гольф, преферанс, рыбалка), топос («бульвар, скамеечка», кабаки, бары, клубы), пища, одежда и т. д.

В анекдотах «про ад на земле» ситуация обратная: в них не воображенческое предстает как реальное и привычное, а реальное и материальное ${ }^{32}$ - как адское в смысле «мучительное и невыносимое». Более того, в оценке персонажей, попавших в пекло после смерти, ад подземный не выдерживает сравнения с адом земным. Хуже преисподней оказывается санаторий (см. сноску 9), семейная жизнь (www.aforizmov. net/anekdoty/tags/ad/page/2/), работа в школе и поступки людей ${ }^{33}$. Инспекторы ГИБДД - ничуть не лучше чертей ${ }^{34}$, впрочем, люди способны стать чертями «на том свете» в результате своего поведения на этом ${ }^{35}$.

32 - Что такое рай на земле? - Рай на земле - это американская зарплата, английский дом, китайская еда и русская жена. - А что тогда ад на земле? - Ад на земле - это американская жена, английская еда, китайский дом и русская зарплата.

33 1) Умер старьй учитель и попал в ад. К нему приходит через неделю Главный смотритель ада и говорит: - Извините, пожалуйста, тут ошибка выила. Вам положено быть в раю. - Нет уж, извините, мне и тут хорошо, - отвечает учитель. - После школь мне ад раем кажется. 2) Портной приходит к своему должнику с угрозой: - Если вы мне сейчас же не заплатите, я преврашу вашу жизнь в ад. - Каким же образом? - Я расскажу всем вашим кредиторам, ито вы отдали мне доле.

34 Гибэдэдэшник остановил священника: - Батюшка, вы нарушили... - Ах, простите меня, сын мой! - Хорошо, я не буду вас штрафовать если вы честно мне скажете: есть ли Бог? - Не знаю... - А рай? - Рая нет. - А ад есть? - И ада нет. - Почему это? - Видишь ли, сын мой, всю смолу взяли на асфальтнье дороги, а вас - чертей - регулировщиками поставили...

35 Два студента: - Давай над деканом приколемся. - Ну давай. Чуть позже, два солдата: - Давай над прапором приколемся. - Ну давай. Еще чуть позже, два зека: - Давай над паханом приколемся. - Ну давай. И еще чуть позже, два черта в аду: - Давай над дьяволом приколемся. - Давай, может в рай попадем. Сидят два студента... 
В двух анекдотах ад подземный в качестве сдерживающего фактора на земле не только теряет свой вес и значение ${ }^{36}$, но и превращается в предмет купли-продажи (http://anek-dot.ucoz.ru/news/rabinovich_ kupil_ad/2012-08-10-6612).

Если говорить о языковой форме рассматриваемого концепта, то в анекдотах самой частотной словоформой является $a \partial$; в девяти анекдотах появляется пекло и в двух - преисподняя.

В шести референциальных анекдотах «про ад» пекло - понятийный эквивалент $a \partial a^{37}$, т. е. место пребывания грешников после смерти. Поскольку смысловое наполнение концептов ад и пекло в них полностью совпадает, можно утверждать, что концепту не-райская часть «того света» соответствуют два имени ад и пекло. Однако в ситуативных анекдотах «про ад на земле» смыслы концептов ад и пекло не одинаковы, т. к. понятийная ступень концепта: а) пекло обогащается небуквальными смыслами солние палит и жа$p a^{38}$; б) ад обогащается небуквальными смыслами жарища, нечто чувственно воспринимаемое и нечто материальное и доступное на земле $e^{39}$. Одним словом, в двух ситуативных анекдотах «про ад на земле» пекло является самостоятельным концептом и составляющей

36 Армянское радио спрашивают: - Почему криминал в последнее время совсем страх потерял, уже ничего не бояться, людей как скот режут? - А вы разве не знаете? Ельиин с Гайдаром уже полностью развалили ад, людям больше нечего бояться!

37 А) Структура концепта подробно описана в: Макаровска 2014, с. 32-42. Б) Только в одном анекдоте ад показан как ассоциат гейзера ( $У x \mathrm{mbl,} \mathrm{глубоко} \mathrm{и} \mathrm{дымнн!} \mathrm{Тебе}$ не напоминает это ад, Билли?).

38 Соответственно: 1) Сидит мужик на берегу Нила и рыбу ловит. Жара жуткая, духота, пекло, да еще и рыба не ловится... Час сидит мужик, два сидит, а рыба все не ловится. Вдруг вспльвает крокодил и так у мужика участливо спрашивает: - Что, жарко? - Угу... - Душно? - Угу... - (с надеждой...) Может, тогда искупнешься? 2) - У нас прошльм летом стояла такая жара, что даже ночью нельзя было выйти на уличу. - Это еще ничего. Вот в нашем городе было настоящее пекло. Хозяйки укрывали несушек льдом, а то яйча оказывались сразу сваренными вкрутую.

39 Соответственно: 1) Едут два кавказца в дорогой иномарке, а на улице жара, просто ад... В машине окна закрытыл, едут в пиджаках и при галстуках все как положено. И тут один говорит: - Слушай, а давай окно хоть чуть-чуть откроем! - Не надо! Пускай все люди думают, что у нас а машине кондичионер... 2) Теща спрашивает зятя: - Ть чего невесельй? - Не выспался. - А чего так? - Разверзлись врата ада, и хор сотен истязаемых душ заполонил уличу... - В детском саду под твоими окнами детвору выцуливали? 3) Наркоман садится в автобусе около старушки. - Вы знаете, - говорит старушка, - ведь вы попадете прямо в ад, молодой человек. Нарик вскочил и закричал водителю: - Остановитесь и выпустите меня, я сел не в тот автобус!!! 
концептосферы ад. Впрочем, как и концепт преисподняя, появляющийся в двух референциальных анекдотах и отличающийся скромным смысловым наполнением, ибо обозначает лишь место, куда попадают новопреставившиеся (Брежнев попал в преисподнюю. Собралась вокруг куча вампиров. - Братџы, кто будет 5 звезд с горла, налетай!).

Кроме референциальных анекдотов, выборка включает три лингвистических анекдота. В одном из них преисподняя есть синоним ада (Вовочка: - Мам, синоним ада, 11 букв, начинается на П... - Преисnодняя? - Не-a, понедельник). В остальных обыгрываются такие смыслы концепта пекло, как: 1) буквальный и небуквальный, т. е. место в загробном мире и жарища; 2) небуквальные страшное место, где лучше, чем дома и комбортное место ${ }^{40}$.

Итак, концептосфера анекдотного ада включает концепт преиспод-

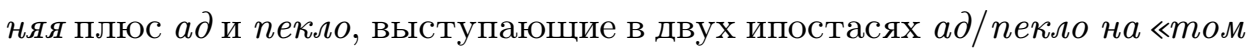
свете» и ад/пекло на земле. Представим в более наглядной форме понятийный и концептный уровни концепта $a \partial$, воплощающегося в русских интернет-анекдотах.

Таблица 1. Понятийный уровень составляющих концептосферы ад

\begin{tabular}{|c|c|c|c|}
\hline \multirow{2}{*}{\multicolumn{2}{|c|}{$\begin{array}{c}\text { Составляющие } \\
\text { концептосферы } \\
\text { концепта } a d\end{array}$}} & \multicolumn{2}{|c|}{ Понятийный уровень концепта } \\
\hline & & Буквальные смыслы & Небуквальные смыслы \\
\hline \multirow[t]{2}{*}{ АД } & $\begin{array}{c}\text { на «том } \\
\text { свете» }\end{array}$ & $\begin{array}{l}\text { - место пребывания } \\
\text { грешников после } \\
\text { смерти }\end{array}$ & - \\
\hline & на земле & $\begin{array}{l}\text { - нечто мучительное } \\
\text { и невыносимое }\end{array}$ & $\begin{array}{l}\text { - жарища } \\
\text { - нечто чувственно воспринимаемое } \\
\text { - нечто материальное и доступное } \\
\text { на земле } \\
\text { Контекстуальные смыслы: } \\
\text { - санаторий, семейная жизнь, } \\
\text { работа в школе, поступки людей, } \\
\text { гуляющие детсадники под окном }\end{array}$ \\
\hline
\end{tabular}

40 Соответственно: 1) Рабинович уехал на ПМЖ в Израиль. Посылает телеграмму родным «Прибыл на место, пекло страшное». По ошибке телеграмму приносят вдове другого Рабиновича, которьй недавно скончался... 2) Идет бракоразводньии прочесс. Муж жалуется, ито у него дома невыносимье условия: - Я готов убежать хоть в пекло! Жена вставляет реплику: - Видите, какой эгоист. Всегда ищет для себя тепленькое местечко. 


\begin{tabular}{|c|c|c|c|}
\hline \multirow{2}{*}{\multicolumn{2}{|c|}{$\begin{array}{c}\text { Составляющие } \\
\text { концептосферы } \\
\text { концепта } а \partial\end{array}$}} & \multicolumn{2}{|c|}{ Понятийный уровень концепта } \\
\hline & & \multirow{2}{*}{$\begin{array}{l}\text { Буквальные смыслы } \\
\text { - место пребывания } \\
\text { грешников после } \\
\text { смерти } \\
\text { - место в загробном } \\
\text { мире* }\end{array}$} & \multirow[t]{2}{*}{ Небуквальные смыслы } \\
\hline ПЕКЛО & $\begin{array}{l}\text { на «том } \\
\text { свете» }\end{array}$ & & \\
\hline & на земле & $\begin{array}{l}\text { - нечто мучительное } \\
\text { и невыносимое }\end{array}$ & $\begin{array}{l}\text { - жарища*, жара } \\
\text { - солнце палит } \\
\text { - комфортное место* } \\
\text { - страшное место, где лучше, чем } \\
\text { дома* }\end{array}$ \\
\hline \multicolumn{2}{|c|}{ ПРЕИСПОДНЯЯ } & $\begin{array}{l}\text { - место, куда попа- } \\
\text { дают умершие } \\
\text { - то же, что ад* }\end{array}$ & - \\
\hline \multicolumn{4}{|c|}{$\begin{array}{l}\text { Примечание. Смыслы, активизирующиеся в лингвистических анекдотах, } \\
\text { отмечены знаком «*» }\end{array}$} \\
\hline
\end{tabular}

Примечательно, что собственно концептный уровень рассматриваемого концепта является одновременно оригинальной моделью анекдотного ада.

Таблица 2. Концептный уровень концепта ад: анекдотный ад как место

\begin{tabular}{|c|c|c|}
\hline Слот & \multicolumn{2}{|c|}{ Смысловое «наполнение» слота } \\
\hline $\begin{array}{c}\text { Местоположение } \\
\text { ада на «том } \\
\text { свете» }\end{array}$ & \multicolumn{2}{|c|}{$\begin{array}{l}\text { - неопределенное } \\
\text { - определенное: ниже рая, рядом с раем (через стенку), там } \\
\text { же, где рай } \\
\text { Путь из ада в рай: вход через врата, дорога, тропинка. } \\
\text { Средства перемещения: лифт, поезд, пешком. }\end{array}$} \\
\hline Структура ада & $\begin{array}{l}\text { многоуровневая } \\
-7 \text { кругов } \\
- \text { на четвертом } \\
\text { уровне есть се- } \\
\text { кретная дверь, } \\
\text { за ней - комната } \\
\text { с бензопилами } \\
\text { - под адом нахо- } \\
\text { дится бар }\end{array}$ & $\begin{array}{l}\text { одноуровневая } \\
\text { 1) в виде коридора со множеством } \\
\text { дверей } \\
\text { 2) в виде свободного пространства } \\
\text { с разделением на } 2 \text { ада/части: } \\
\text { - социалистический - капитали- } \\
\text { стический } \\
\text { - американский/немецкий - рус- } \\
\text { ский } \\
\text { - школьный/обычный - студен- } \\
\text { ческий } \\
\text { - для безбожников - для верую- } \\
\text { щих грешников } \\
\text { 3) без разделения на зоны как место } \\
\text { мучений или утех } \\
\text { 4) для конкретных специалистов - } \\
\text { компьютерный ад }\end{array}$ \\
\hline
\end{tabular}




\begin{tabular}{|c|c|}
\hline Слот & Смысловое «наполнение» слота \\
\hline Подобие до рая & $\begin{array}{l}\text { - ад = точная копия традиционного рая } \\
- \text { рай = точная копия традиционного ада } \\
\text { - ад = копия малокомфортабельного рая (тесная прокурен- } \\
\text { ная комната, помещение вычислительного центра) } \\
\text { - ад отличается от рая одним элементом } \\
\text { - ад } \neq \text { рай, где ад = геенна огненная, рай }=\text { место вечного } \\
\text { наслаждения }\end{array}$ \\
\hline $\begin{array}{c}\text { Связь с раем, } \\
\text { контакты }\end{array}$ & $\begin{array}{l}\text { - через адово посольство в раю, по телефону, с помощью } \\
\text { телевизора, личного общения и писем } \\
\text { - обращение за помощью к Богу в случае разрушительных } \\
\text { действий грешников и их пагубного влияния на чертей }\end{array}$ \\
\hline Функции ада & $\begin{array}{l}\text { - наказание грешников } \\
\text { - организация порочных утех и развлечений для греш- } \\
\text { ников } \\
\text { - организация порочных утех и развлечений для безбож- } \\
\text { ников и кар для верующих грешников } \\
\text { - создание специальных условий для вечного наслаждения } \\
\text { как награда для праведников }\end{array}$ \\
\hline $\begin{array}{l}\text { Наказание } \\
\text { грешников }\end{array}$ & 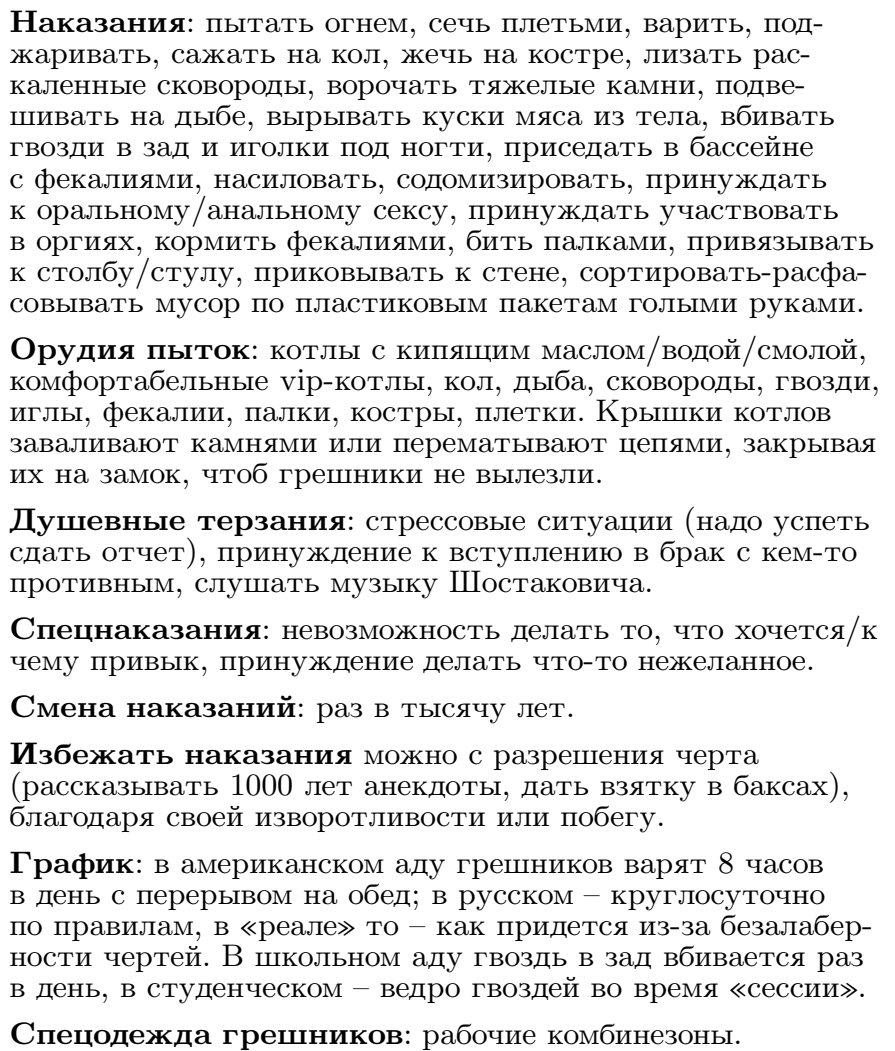 \\
\hline
\end{tabular}




\begin{tabular}{|c|c|}
\hline Слот & Смысловое «наполнение» слота \\
\hline Развлечения в аду & $\begin{array}{l}\text { График: понедельник - день курения; вторник - день } \\
\text { принятия алкоголя; среда - день принятия наркотиков; } \\
\text { четверг - «день повального секса»; пятница - праздник для } \\
\text { гомосексуалов. } \\
\text { Развлечения: пьянки, гулянки, танцы, игра в карты, } \\
\text { партия в гольф, полет на дельтаплане со стерхами, } \\
\text { рыбалка, «девочки», стриптиз, курево, повальный секс. } \\
\text { Пища: балыки, черная икра, ананасы, жареные рябчики, } \\
\text { марципаны, омары, вяленая рыба, «всякие вкусности». } \\
\text { Напитки: пиво, водка, вино граппа, легкие вина, самогон, } \\
\text { спирт. } \\
\text { Наркотики: легкие наркотики, героин, «тяжелая синтети- } \\
\text { ка», гора анаши. } \\
\text { Предметы: дорогие сигары, кальян, махорка, трубка. } \\
\text { Разное: вечная теплая ночь. }\end{array}$ \\
\hline $\begin{array}{c}\text { Как попасть в ад, } \\
\text { возможности }\end{array}$ & $\begin{array}{l}\text { В ад можно попасть: по спискам, по решению Страшно- } \\
\text { го Суда, Святого Петра, Архангелов, ангелов, Архангела } \\
\text { Гавриила, Господа, в результате дискуссии Бога/ангела } \\
\text { с Сатаной/чертом, по ошибке, по собственному желанию. } \\
\text { Возможность: выбора ада или рая, места в аду и формы } \\
\text { наказания, перейти в рай после отбывания наказания, } \\
\text { отправиться обратно на землю, получить возможность } \\
\text { исполнения } 3 \text { желаний. } \\
\text { Предварительные испытания перед тем, как по- } \\
\text { пасть в ад или рай: } \\
\text { - у св. Петра - ответить на вопрос, выдержать удар } \\
\text { книгой своих грехов по голове } \\
\text { - у черта - выдержать удар кнутом }\end{array}$ \\
\hline $\begin{array}{l}\text { Праздники, } \\
\text { реклама ада, } \\
\text { экскурсии, } \\
\text { мероприятия }\end{array}$ & $\begin{array}{l}\text { Праздник: раз в год отключение горячей воды. } \\
\text { Цель рекламы и экскурсий: } \\
\text { - привлечь туристов } \\
\text { - как эффект разрешения грешникам выбрать рай/ад, } \\
\text { место в аду или наказание } \\
\text { - заманить праведников } \\
\text { Мероприятия: аудит, инвентаризация котлов, комиссия. }\end{array}$ \\
\hline Топос & $\begin{array}{l}\text { «бульвар, скамеечка», бары, клубы, рестораны, казино, } \\
\text { бордель, кабак, музей, кино, библиотека }\end{array}$ \\
\hline $\begin{array}{l}\text { Помещения } \\
\text { и предметы }\end{array}$ & $\begin{array}{l}\text { - пыточные, VIP-залы, комната страшная и ужасная, } \\
\text { «тесная прокуренная комнатенка», «плавательный } \\
\text { бассейн, полный дерьма» } \\
\text { - VIP-комнаты: «отдельный номер со всеми удобствами» } \\
\text { для Ф. Кастро/Порошенко; номер для изобретателя } \\
\text { «Виагры»-«громадный зал, убранный персидскими } \\
\text { коврами и шелковыми гобеленами. Летают попугаи, } \\
\text { бьют фонтаны», шелковые подушки; комната для } \\
\text { Б. Гейтса - «с кондиционерами, куча компьютеров, } \\
\text { холодильник полный, еды и пива» }\end{array}$ \\
\hline
\end{tabular}




\begin{tabular}{|c|c|}
\hline Слот & Смысловое «наполнение» слота \\
\hline & $\begin{array}{l}\text { - ярко-зеленое поле для гольфа } \\
\text { - «помещение типа общаги» } \\
\text { - «крутейший компьютерный центр, компы навороченные, } \\
\text { мультимедиа всякие, сервера крутые» } \\
\text { - коридор с дверями в пыточные } \\
\text { - печи, топка, дрова, ведра с дерьмом, гора анаши } \\
\text { Разное: музыка Шостаковича как пытка, крики, стоны. }\end{array}$ \\
\hline $\begin{array}{l}\text { Природное } \\
\text { окружение }\end{array}$ & $\begin{array}{l}\text { - огромная пустыня, заваленная мусором, небо черное от } \\
\quad \text { ворон } \\
\text { - поле конопли } \\
\text { - лес } \\
\text { - деревья, трава из пластика } \\
\text { - ледяное озеро } \\
\text { Разное: вонь невообразимая, запах серы, облака дыма над } \\
\text { котлами, жара }+70^{\circ},+130^{\circ}, \text { мороз }-40^{\circ} .\end{array}$ \\
\hline Животный мир & щуки по 121 кг, стерхи, мухи, вороны \\
\hline
\end{tabular}

Как видим, ад в качестве места амбивалентен и полон контрастов. Весьма интересна персоносфера ада, состоящая из коренных (черти) и пришлых обитателей.

Таблица 3. Концептный уровень концепта ад: персоносфера ада

\begin{tabular}{|c|c|}
\hline Слот & Смысловое «наполнение» слота \\
\hline $\begin{array}{c}\text { Персоносфера } \\
\text { коренных } \\
\text { обитателей }\end{array}$ & $\begin{array}{l}\text { Главный: Сатана, черт, Люцифер, Лукавый, дьявол, } \\
\text { Главный смотритель, Главный. } \\
\text { Остальные: черти, чертенята, Вельзевул, бес, демон, } \\
\text { некто «похожий на человека, но светящийся изнутри } \\
\text { инфракрасным светом». } \\
\text { Должности: стражник, привратник, бармен, крупье, } \\
\text { кочегар, охранник, ревизор. } \\
\text { Внешний вид: у чертей рога, хвосты, кошмарные злые } \\
\text { рожи, свиные рыла, зловещая ухмылка. } \\
\text { Характер: Люцифер гостеприимный; черт/Сатана } \\
\text { стойкий, неуступчивый, глупый, слабонервный; Сатана } \\
\text { - «человек любезный, веселый и симпатичный»; Лука- } \\
\text { вый падок на деньги; черт любит анекдоты; черти - } \\
\text { предприимчивые, хитрые, податливые на коммунистиче- } \\
\text { скую пропаганду, переимчивые, падкие на деньги, легко } \\
\text { адаптируются к навязанным условиям, слабохарактерные, } \\
\text { исполнительные. } \\
\text { В общении: Главный и черти вежливые, коммуника- } \\
\text { бельные, Сатана ласков со студентом, ко всем обращается } \\
\text { на «ты», кроме Кастро, Порошенко, Ельцина, Гундяева. } \\
\text { Одежда и обувь: красный костюм, «черное одеяние», } \\
\text { тапки (только у дьявола). } \\
\text { Аксессуары: кнут, дубина, пика, вилы. }\end{array}$ \\
\hline
\end{tabular}




\begin{tabular}{|c|c|}
\hline Слот & Смысловое «наполнение» слота \\
\hline $\begin{array}{c}\text { Персоносфера } \\
\text { пришлых } \\
\text { обитателей }\end{array}$ & 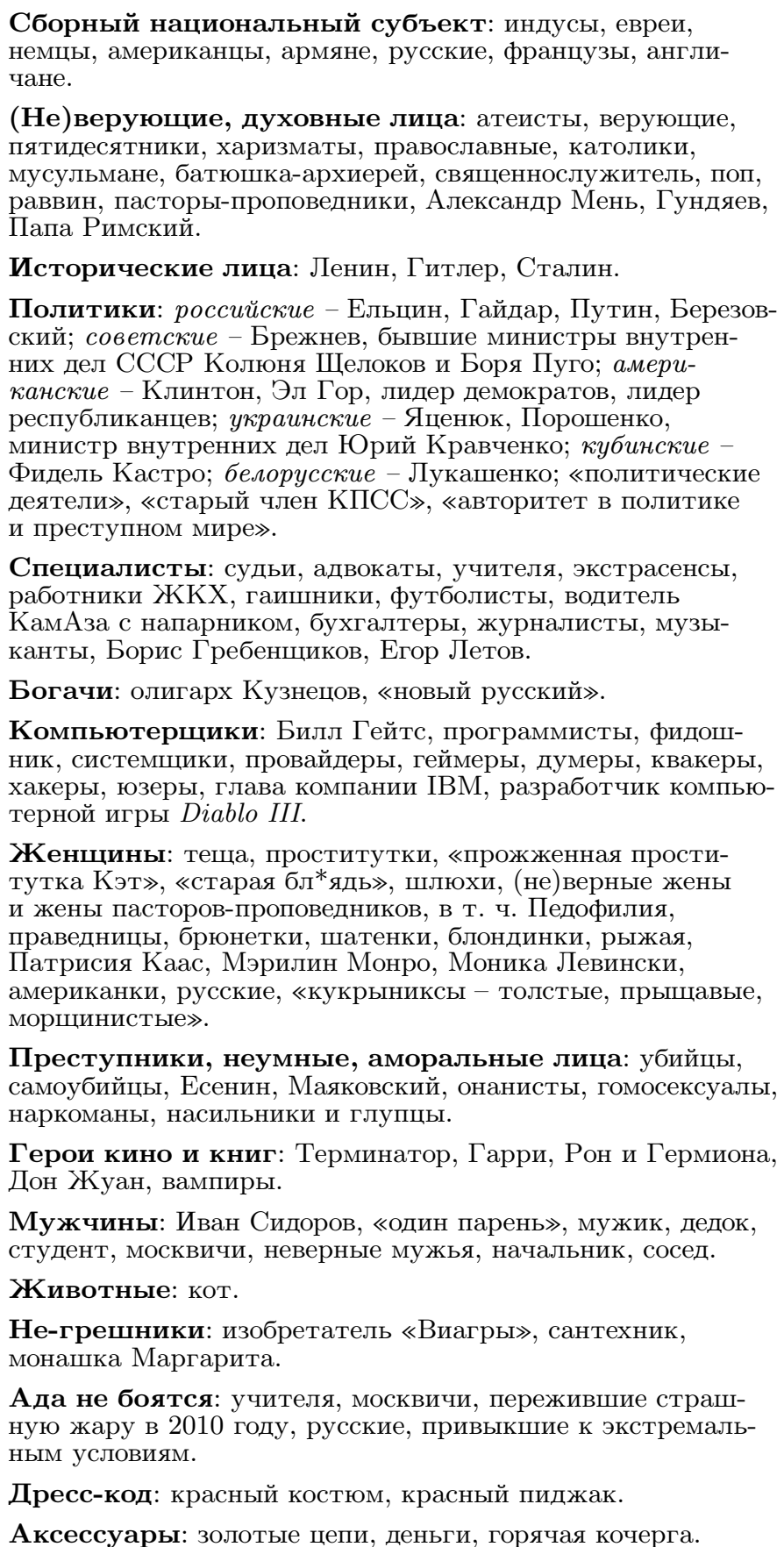 \\
\hline
\end{tabular}


Подводя черту под всем сказанным, нужно подчеркнуть, что концепт ад в интернет-анекдотах больше соответствует народным образам, чем его видению в православии и представлениям интернетчиков. Анекдотный ад рисуется как нечто материальное и телесное (душевные муки лишь подразумеваются), привычное (к миру фантастическому принадлежат лишь черти и небожители, изредка заглядывающие в пекло), теплое и шумное, часто приятно удивляющее и совсем не страшное (особенно для экстремалов, геймеров, проституток, некоторых политиков, коммунистов), а если жуткое, то и так не ужаснее ада на земле. Разные новшества (VIP-комнаты, кальяны, секс-кукла, компьютеры, неоновая реклама, экскурсии и пр.), популярные обитатели (Билл Гейтс, Терминатор, Гермиона и др.), знакомые ситуации (комиссии, аудит) сближают ад с современным земным миром; а предметы традиционного быта (дрова, печка, вилы), исторические лица и персонажи минувших времен (Ленин, Сталин, Брежнев) - с земным былым. Все это плюс необычное изображение ада в качестве гостеприимного пристанища для грешников, не только превращает его, пользуясь словами М. М. Бахтина, в «веселое карнавальное страшилище», но и способствует, как ни парадоксально, формированию позитивного настроя на ад, места, изначально не радостного, ибо связанного со смертью.

Таким образом, наличие интернет-анекдотов «про ад» и факт, что объективация концепта ад в них и в народных представлениях значительно не разнятся, благодаря преобладанию традиционных составляющих и гармоничному сосуществованию нового и старого, есть свидетельство прочного укоренения концепта $а д$ в национальной картине мира русских как значимого элемента христианского наследия.

\section{Литература}

Ерофеев Ю.В., 2010, Интернет-анекдот как особый вид юмористического дискурса, "Известия Самарского научного центра Российской академии наук", т. 12, № 3, с. 163-166, [online], http://www.ssc.smr.ru/media/ journals/izvestia/2010/2010_3_163_166.pdf, [28.03.2015].

Кирилл (Зинковский) иеромонах, 2010, Bопросы об аде и рае (вопросы задавал А. Бакулин), [в:] Православный Санкт-Петербург, [online], http:// www.pravoslavie.ru/smi/38179.htm, [05.02.2015].

Климов Г. протоиерей, 2013, Что такое ад? (подготовила И. Лухманова), [в:] Нескучный сад, [online], http://vichuga-voskr.cerkov.ru/2013/08/22/ chto-takoe-ad/, [05.02.2015]. 
Лесной С., 1995, Откуда mbl, Русь?, Ростов-на-Дону, [online], http://www.kir soft.com.ru/freedom/KSNews_527.htm, [05.02.2015].

«Навечно во тьме». Природа и причина вечных мук. По изданию 1863 го$\partial a \ll O$ вечныхх мучениях грешников», 2004, Москва, [online], http://www. golden-ship.ru/knigi/4/NVT.htm\#q1, [13.03.2015].

Полный православный богословский энциклопедический словарь, 1992, том 1, Москва.

Симеон Новый Богослов преп., Божественные Гимны, 2010, Библиотека Золотой Корабль.RU 2010, [online], http://www.golden-ship.ru/knigi/3/simeon NB-BG.htm\#_Toc221206566, [09.03.2015].

Толстой Н.И., (ред.), 1995, Славянские древности, том 1, Москва.

Толстой Н.И., (ред.), 2012, Славянские древности, том 5, Москва.

Шмелева Е.Я., Шмелев А.Д., 2002, Русский анекдот. Текст и речевой жанр, Москва.

Gieysztor A., 2006, Mitologia Stowian, Warszawa.

Gigilewicz E., (red.), 2011, Encyklopedia katolicka, tom XV, Lublin.

Makarowska O., 2014, Культурнье, культурно-личностньее и коммуникативно-стилевые детерминанты интерперсональной коммуникачии между польской и русской молодежью, Poznań.

\title{
THE CONCEPT OF HELL IN RUSSIAN INTERNET JOKES
}

\author{
S U M M A R Y
}

This article analyses new ways of understanding hell by the Russians based on the examples of Internet joke texts. For the sake of this analysis 160 anecdotes have been selected from theme portals (Anekdoty.ru), social media (Wkontakte), forums, etc. The idea of hell emerging from the texts of the jokes largely corresponds with a traditional Russian idea of hell, the place where sinners are punished. However, a number of new elements have been discovered, such as VIP rooms, a neon advertisement, restaurants, and so forth. Surprisingly enough, the jokes depict hell as the place where sinners can have a good time. This article draws analogies between Hell and the Earth; it also describes those dwelling in hell, mostly devils and sinners. The comparison of the idea of hell from the Internet jokes with the idea of hell described in Russian forums has shown some considerable differences in the perception of hell as a concept. 
